\title{
Hyphodontia (Hymenochaetales, Basidiomycota) and similar taxa from Central Asia
}

\begin{tabular}{|c|c|}
\hline Journal: & Botany \\
\hline Manuscript ID & cjb-2017-0115.R1 \\
\hline Manuscript Type: & Article \\
\hline Date Submitted by the Author: & 21-Aug-2017 \\
\hline Complete List of Authors: & $\begin{array}{l}\text { Gafforov, Yusufjon; Institute of Botany and Zoology, Academy of Sciences } \\
\text { of the Republic of Uzbekistan, Mycology; Universitat Kassel Institut fur } \\
\text { Biologie, Department of Ecology; Instituto de Botanica de Sao Paulo, } \\
\text { Núcleo de Pesquisa em Micologia, Centro de Pesquisa em Plantas } \\
\text { Avasculares e Fungos } \\
\text { Riebesehl, Janett ; Universitat Kassel Institut fur Biologie, Department of } \\
\text { Ecology } \\
\text { Ordynets, Alexander; Universitat Kassel Institut fur Biologie, Department of } \\
\text { Ecology } \\
\text { Langer, Ewald ; Universitat Kassel Institut fur Biologie, Department of } \\
\text { Ecology } \\
\text { Yarasheva, Manzura; Institute of Microbiology of the Academy of Sciences } \\
\text { of the Republic of Uzbekistan } \\
\text { Ghobad-Nejhad, Masoomeh; Iranian Research Organization for Science and } \\
\text { Technology (IROST), Department of Biotechnology } \\
\text { Zhou, Li-Wei; Institute of Applied Ecology, Chinese Academy of Sciences, } \\
\text { Biodiversity (Fungus) } \\
\text { Wang, Xue-Wei ; Institute of Applied Ecology, Chinese Academy of } \\
\text { Sciences, Biodiversity (Fungus) } \\
\text { Gugliotta, Adriana; Instituto de Botanica de Sao Paulo, Núcleo de Pesquisa } \\
\text { em Micologia, Centro de Pesquisa em Plantas Avasculares e Fungos }\end{array}$ \\
\hline $\begin{array}{r}\text { Is the invited manuscript for } \\
\text { consideration in a Special } \\
\text { Issue? : }\end{array}$ & N/A \\
\hline Keyword: & Taxonomy, ITS, wood-inhabiting basidiomycetes, global distribution, GIS \\
\hline
\end{tabular}




\section{Hyphodontia (Hymenochaetales, Basidiomycota) and similar taxa from Central Asia}

2

3 Yusufjon Gafforov ${ }^{1,2,6^{*}}$, Janett Riebesehl ${ }^{2}$, Alexander Ordynets ${ }^{2}$, Ewald Langer ${ }^{2}$, Manzura Yarasheva $^{3}$, 4 Masoomeh Ghobad-Nejhad $^{4}$, Li-Wei Zhou $^{5}$, Xue-Wei Wang ${ }^{5}$ and Adriana de Mello Gugliotta ${ }^{6}$

$6{ }^{1}$ Laboratory of Mycology, Institute of Botany and Zoology, Academy of Sciences of the Republic of 7 Uzbekistan, 232 Bogishamol Street, Tashkent 100053, Uzbekistan, yugafforov@yahoo.com

$8{ }^{2}$ Department of Ecology, University of Kassel, Heinrich-Plett-Str. 40, DE-34132 Kassel, Germany, 9 riebesehl@uni-kassel.de, a.ordynets@uni-kassel.de, ewald.langer@uni-kassel.de

$10{ }^{3}$ Institute of Microbiology of the Academy of Sciences of the Republic of Uzbekistan, 7B A. Kadyri 11 Street, 100128, Tashkent, Uzbekistan, manzur@inbox.ru

$12{ }^{4}$ Department of Biotechnology, Iranian Research Organization for Science and Technology (IROST), P. O. Box 33535111, Tehran 3353136846, Iran, ghobadnejhad@gmail.com

145 Institute of Applied Ecology, Chinese Academy of Sciences, 110016 Shenyang, China, 15 liwei_zhou1982@163.com

$16{ }^{6}$ Núcleo de Pesquisa em Micologia, Centro de Pesquisa em Plantas Avasculares e Fungos, Instituto de 17 Botânica, Av. Miguel Stéfano, 3687 - Vila Agua Funda, São Paulo - SP, 04301-902, Brazil, 18 agugliotta@ibot.sp.gov.br

*Corresponding author: Yusufjon Gafforov, Laboratory of Mycology, Institute of Botany and 21 Zoology, Academy of Sciences of the Republic of Uzbekistan, e-mail: yugafforov@yahoo.com Phone: +998712890465 


\section{Abstract}

25 Wood-inhabiting fungi are noteworthy components of woody ecosystems which are responsible for the 26 decomposition and turnover of wood nutrients. While the diversity and ecology of these fungi in the 27 temperate forests has been relatively well explored, little is known on diversity of these fungi in the arid and semi-arid forest ecosystems. This is the first study on diversity, distribution and ecology of the fungal genus Hyphodontia s.l. in the five countries of Central Asia viz., Kazakhstan, Kyrgyzstan, Tajikistan, Turkmenistan and Uzbekistan. Altogether 11 species are confirmed for the region, among which the following six species are reported for the first time from Central Asia: Hyphodontia alutaria, H. pallidula, Kneiffiella alutacea, Lyomyces crustosus, L. erastii and L. sambuci. In addition to morphological evidence, the identity of three species is confirmed with phylogenetic analysis based on ITS nuclear ribosomal DNA region. The spectra of known hosts for many of the studied species were expanded. An annotated species list and geo-referenced distribution maps are provided as well as notes on taxonomy, ecology, and local, regional and global distribution. An identification key to the species of Hyphodontia s.l. recorded in arid and semi-arid regions of Central Asia is also provided.

Key words: Taxonomy, ITS, wood-inhabiting basidiomycetes, global distribution, GIS, Central Asia, 


\section{Introduction}

43 Wood-inhabiting fungi are noteworthy components of woody plant ecosystems and take an active part

44 in decomposition and turnover of wood nutrients. Corticioid fungi are one of the major groups of 45 wood-inhabiting basidiomycetes (Larsson 2007), although some of them are mycorrhizal.

46 Morphologically, this group has holobasidia and effused basidiomata, with a smooth, wrinkled, toothy, 47 or somewhat poroid hymenophore (Dai 2011, 2012). The majority of the corticioid species function as white rot wood decomposers (Swift 1982). Current molecular systematic research confirms that corticioid fungi are phylogenetically heterogeneous and distributed among all major clades within Agaricomycetes (Hibbett et al. 2007; Larsson 2007).

The genus Hyphodontia (Fr.) J. Erikss. is one of the most species-rich genera of corticioid fungi. The genus was first described by Eriksson in 1958 and belongs to the order Hymenochaetales, class Agaricomycetes. Species in Hyphodontia s.1. have resupinate basidiomata with variable micro- and macromorphology, usually distinguished by a toothy hymenophore; smooth or poroid hymenophores are present in some species. The hyphal system is monomitic and hyphae generally have distinct to somewhat thickened walls and small semicircular clamps, basidia subclavate to suburniform with allantoid, ellipsoid to subglobose basidiospores that are thin-walled, usually with one or two guttules (Eriksson and Ryvarden 1976).

Hyphodontia s.l. species are wood-decaying saprobes, causing a white rot in deciduous and coniferous woody plants and therefore participating in carbon recycling of forest ecosystems (Eriksson and Ryvarden 1976). Hyphodontia s.l. was monographed on a world scale by Langer (1994), who provided descriptions and keys for the identification of the species. A global morphological key has been recently updated by Yurchenko and $\mathrm{Wu}$ (2016) and Riebesehl and Langer (2017). Most Hyphodontia s.l. species have been described from the Neotropics, Paleotropics and Holarctic Region 
2006; Langer 1994, 1998; Ginns 1998; Langer and Dai 1998; Greslebin and Rajchenberg 2000, 2003;

Kotiranta and Saarenoksa 2000; Dai 2011; Bernicchia and Gorjón 2010; Lee and Langer 2012; Gorjón 2012; Riebesehl et al. 2015; Chen et al. 2016). Recently new species of Hyphodontia s.l. have been discovered from Asia and Réunion Island (Maekawa 1993, 1994, 2000; Xiong et al. 2009, 2010; Yurchenko and Wu 2013, 2014; Zhao et al. 2014; Riebesehl et al. 2015; Chen et al. 2016; Chen et al. 2017; Kan et al. 2017a; Kan et al. 2017b). Currently, 125 Hyphodontia s.l. species are recognized in the world (Riebesehl and Langer 2017; Chen et al. 2017; Kan et al. 2017a; Kan et al. 2017b). In Central Asia, four species have been reported from Kazakhstan, one species from Kyrgyzstan and one from Uzbekistan (Schwartsman 1964; Eljchibayev 1966; Kan et al. 2017a). However the knowledge of Hyphodontia species in Central Asia is very poor.

Based on morphological characters, Hjortstam and Ryvarden (2009) proposed splitting Hyphodontia s.l. into 13 separate genera. Recent molecular phylogenies (Larsson et al. 2006; Yurchenko and Wu 2014; Riebesehl and Langer 2017) inferred from ribosomal DNA sequence data demonstrated the polyphyletic nature of Hyphodontia s.1. Yurchenko and $\mathrm{Wu}$ (2014) distinguished twelve clades, but without sufficient support for the derivative genera. Riebesehl and Langer (2017) classified the species into seven genera: Hastodontia (Parmasto) Hjortstam \& Ryvarden, Hyphodontia J. Erikss., Kneiffiella P. Karst., Lagarobasidium Jülich, Lyomyces P. Karst., Palifer Stalpers and P.K. Buchanan and Xylodon (Pers.) Gray. We are following the classification of Riebesehl and Langer (2017) in this paper.

The aim of this study is making an overview on the diversity and distribution of the Central Asian Hyphodontia s.l. species, reporting new records, discussing the accepted species from the region, as well as providing phylogenetic analyses of the species discussed. A checklist and a key to the species are provided, and the current knowledge of the genus in the five countries of Central Asia is discussed.

\section{Materials and methods}


91

92

93

94

95

The study area

In this article, Central Asia is regarded as the region covering Kazakhstan, Kyrgyzstan, Tajikistan, Turkmenistan and Uzbekistan. According to the WWF Ecozones system, Central Asia is part of the Palearctic ecozone (Olson et al. 2001). The region has varied geography, including high mountains of Tien-Shan and Pamir-Alai, vast deserts of Kara-Kum (Black Sand), Kyzyl-Kum (Red Sand), Taklamakan, and large and mostly treeless grassy steppes. The vast steppe areas of Central Asia, together with the steppes of Eastern Europe, are considered a homogenous geographical zone known as the Eurasian steppe. Much of the area consists of steep mountain ranges reaching 7,495 $\mathrm{m}$ in elevation, largely covered by rock and devoid of extensive vegetation. Lowlands stretch from north to south for more than $3,000 \mathrm{~km}$, and there is a gradient from a mixed deciduous forests to forest-steppe and steppe zones and finally to semi-arid and arid zones.

The largest biomes in Central Asia are temperate grasslands, savannas, and shrublands biome. Central Asia also contains mountain grasslands and shrublands, deserts and xeric shrublands as well as temperate coniferous forests biomes. Despite the mountainous nature of Central Asia, forests cover a relatively small proportion of each country. Much of the forest area is dominated by small trees of the genus Haloxylon Bunge ex E. Fenzl (Amaranthaceae) and other shrubs, particularly in desert and semidesert areas of Central Asia. In moist, mountainous areas the main species are juniper (Juniperus spp.), Asian spruce (Picea schrenkiana Fisch. \& C.A. Mey.), Siberian fir (Abies sibirica Ledeb.), poplar (Populus spp.), willow (Salix spp.), walnut (Juglans regia L.), pistachio (Pistacia vera L.), apple (Malus sieversii (Ledeb.) M.Roem., and M. niedzwetzkyana Dieck ex Koehne), almond (Amygdalus communis L.), wild plum (Prunus sogdiana Vassilcz.), wild cherry (Prunus ferganica Lincz), mountain ash (Sorbus persica Hedl.), wild pear (Pyrus bucharica Litv., and P. korschinskyi Litv.) and other deciduous forest trees, fruit-bearing trees, and shrubs. Climate is decidedly continental, arid and semi-arid with low annual precipitation, cloudless, hot, dry summers and moist, relatively warm 
115

116

117

118

119

120

121

122

123

124

125

126

127

128

129

130

131

132

133

134

135

136

137

138

139

winters in the south and cold winters with severe frosts in the north (Klein Tank et al. 2006; Lioubimtseva 2009).

\section{Collection and preservation of samples}

This study was based on fresh samples collected during recent field surveys of wood-inhabiting basidiomycetes from Tashkent province in the north-eastern Uzbekistan. The authors collected Hyphodontia-like species in the Tashkent Botanical Garden (4120'37.67" N, 69¹8'57.83" E) in September of 2013 and Ugam-Chatkal State National Natural Park (41 ${ }^{\circ} 55^{\prime} 31.12^{\prime \prime}$ N, 70³4'27.09" E) in October and November of 2011. The national park is the important nature park of Uzbekistan on the southern slopes of the western part of Tien Shan Mountains as conservation of plants, animals and fungi, revision of fungal herbarium specimens, and bibliographic references. The authors had a chance to study part of the valuable fungal collections made by Estonian mycologists in Central Asia, deposited at Mycological herbarium TAAM, Estonian University of Life Sciences, Tartu, Estonia. The recently collected samples and duplicate specimens of Hyphodontia s.l. species from TAAM are deposited at TASM (Tashkent Mycological herbarium), Institute of Botany and Zoology, Uzbek Academy of Science, Uzbekistan. We re-examined 30 Hyphodontia s.1. specimens from TAAM. Each specimen is mentioned in the text with herbarium number and collection date. Herbarium acronyms used in the paper are from Index Herbariorum (Thiers, continuously updated).

\section{Morphological examination}

For the observation of specimens, laboratory techniques described by Largent et al. (1977) were used. Microscopic sections of basidiomes were examined in 5\% aqueous $\mathrm{KOH}$ plus $1 \%$ phloxine solutions, Melzer's reagent (Hawksworth et al. 1995; Kirk et al. 2008) for amyloid or dextrinoid reactions, and Cotton Blue in lactic acid (Hjortstam 1983) for cyanophily. Basidiome and hymenophoral morphology were observed and photographed with Leica M165 FC stereomicroscope. 
140 Measurements were made digitally from slide stained preparations observed under a Leica DM6000 B

141 microscope. Descriptive terminology for taxonomic characters was taken from Langer (1994) and Kirk

142 et al. (2008). Common color names have been used according to Petersen (1996). The species names

143 follow Riebesehl and Langer (2017); host tree names follow ThePlantList (2013).

Molecular work

Six taxa with positive results in polymerase chain reaction (PCR) were selected for molecular study, represented by specimens recently collected in Uzbekistan and Kazakhstan. Genomic DNA was extracted as described in Gafforov et al. (2014). The amplification by PCR of internal transcribed spacer (ITS) was performed using primers ITS1F/ITS4 or ITS1/ITS4 (White et al. 1990; Gardes and Bruns 1993). Sequencing was performed by Macrogen Inc., Seoul, Korea, utilizing ABI 3730 XL automated sequencers (Applied Biosystems) using primers ITS1/ITS4. The raw sequence data were aligned using MEGA7 (Kumar et al. 2016). The assembled sequences obtained in this study were deposited in NCBI GenBank. Each sequence was compared to the reference sequences in GenBank, using a BLAST search (http://blast.ncbi.nlm.nih.gov/Blast.cgi). Accordingly, some ITS sequences were downloaded from GenBank and incorporated with the newly generated ITS sequences in a dataset (Table 1). Phellinus gabonensis Decock \& Yombiyeni (Yombiyeni et al. 2011), another member of Hymenochaetales, was chosen as outgroup (following Riebesehl and Langer 2017). The alignment was calculated with MAFFT version 7 (Katoh and Standley 2013), using L-INS-i algorithm. The data matrix consisted of 64 sequences with ITS1, 5.8S gene and ITS2; six of them were generated 160 in this study (Table 1).

Two different phylogenetic analyses were calculated. The Minimum Evolution phylogram was constructed in MEGA7 with default settings, using Tamura-Nei model, partial deletion for gaps and 1000 bootstrap (BS) replications. The Bayesian analysis was done with MrBayes 3.2.6 (Ronquist and 
164 Huelsenbeck 2003), using default settings with 200,000 generations and one saved tree every 1000 165 generations. MEGA7 and FigTree 1.4.2 (Rambaut 2012) were used for processing the phylograms.

166

167

168

169

170

171

172

173

174

175

176

177

178

179

180

181

182

183

184

185

186

187

188

Data compilation for GIS Map

A point distribution map of Hyphodontia s.1. species (Fig 1) were produced using the ArcGIS 10.1 desktop software. GPS navigation device and Google Earth software were used for geo-referencing recently collected samples in study sites of Hyphodontia s.l. specimens based on herbarium data and relevant literature data. A WGS84 Geographic coordinate system was used as a reference datum. We used for geo-referencing GPS coordinates of Hyphodontia s.l. species in vegetation map of Central Asia used as the layer from Zhou et al. (2015). MODIS and Natural Earth database in the Central Asia map caption, e.g., Fig. 1. Study area. Land cover data was adapted from the $500 \mathrm{~m}$ Moderate Resolution Imaging Spectroradiometer (MODIS) land cover product (MCD12Q1). Data for roads, rivers, lake centerlines, and country boundaries were downloaded from the Natural Earth database (2017).

\section{Results}

\section{Annotated list of Hyphodontia s.l. species from Central Asia}

Information on Hyphodontia s.l. species such as collection date, location, host tree and elevation are provided in Fig. 1, Table 2. Species are listed alphabetically, and records new to Central Asia are marked with an asterisks.

*Hyphodontia alutaria (Burt) J. Erikss., Symb bot upsal 16 (1): 104, 1958.

Since Hyphodontia alutaria is morphologically quite similar to H. zhixiangii and no Central Asian specimens of $H$. alutaria was sequenced, we cannot exclude the possibility that the so-called $H$. alutaria in Central Asia is actually $H$. zhixiangii. At this time, we treat them as $H$. alutaria according 
189 to the morphological concept of $H$. alutaria in a wide sense. This species usually widespread on 190 coniferous trees such as Abies, Cupressus, Juniperus, Picea, Pinus and Taxus, however, Ginns and 191 Lefebvre (1993) reported on Betula, Populus, angiosperm as host plants in North America. In 192 Uzbekistan we found this species on a stem of deciduous tree, Pterocarya pterocarpa (Juglandaceae). 193 Although Xylodon flaviporus (Berk. \& M.A. Curtis ex Cooke) Ghobad-Nejhad and Hallenberg (2012) 194

had been found on Pterocarya fraxinifolia from the Caucasian region, this report is the first for any Hyphodontia s.l. on P. pterocarpa. We also report the first record of H. alutaria on Juniperus polycarpos var. seravschanica, though it was long known to grow on J. communis. Hyphodontia alutaria was collected in dry and moist areas of foothills to mountains with altitude $700-1800 \mathrm{~m}$, indicating that this species is well adapted to a continental environment with high temperature.

Specimens examined: TAJIKISTAN: Khatlon Prov., Hissar mountain range (alt. $1800 \mathrm{~m}$ ) in the 200 Western part of the Pamir-Alay Mountains, on the stem of Juniperus polycarpos var. seravschanica, 201 25 May 1978, I. Parmasto, TAAM 097283; UZBEKISTAN: Tashkent Prov., Botanical garden in 202 203 Tashkent city, on twigs and stem of Pterocarya pterocarpa Kunth ex I. Iljinsk, 2 Sep 2013, Yu. Sh. Gafforov, YG-G37 (TASM).

Global distribution: ASIA: Central Asia: Tajikistan, Uzbekistan; East Asia: China (Dai 2011); 205 South Asia: India (Kaur et al 2014); Armenia (Ghobad-Nejhad 2011), Iran (Ghobad-Nejhad and 206 Hallenberg 2012); EUROPE: many countries (Bernicchia and Gorjón 2010); NORTH AMERICA: Canada, USA (Gilbertson 1980); SOUTH AMERICA: Argentina (Greslebin and Rajchenberg 2000), 208 Colombia (Hjortstam and Ryvarden 2008), Uruguay (Hjortstam and Ryvarden 2007a), Venezuela (Hjortstam and Ryvarden 2005, 2007b); AUSTRALASIA: Australia, New Zealand (Cunningham 1963); SOUTH ATLANTIC OCEAN: St. Helena (Ryvarden 2015).

Hyphodontia arguta (Fr.) J. Erikss., Symb bot upsal 16 (1): 104, 1958. 
In Central Asia, this species is very common, with a wide range of habitat and substrate, growing

from 1600 to $2900 \mathrm{~m}$ elevation and on diverse coniferous and deciduous wood plants in both xeric and

moist mountain forests. This is the first report of this species on dead wood of the Crataegus

songarica, Malus sieversii and Sorbus tianschanica - endemic trees of the Central Asian Mountains.

Our specimens have variable sizes of lagenocystidia. According to Schwartsman (1964) the basidia are

10-15 × 3.6-6 $\mu \mathrm{m}$, and basidiospores 5-6 $\times 4-5 \mu \mathrm{m}$. Here we report the species from the basidiomata

of Phellinus pini. Schwartsman (1964) also reported H. arguta in Kazakhstan as Odontia lactea (P.

Karst.) P. Karst, which is now regarded as a synonym of H. arguta (Index Fungorum 2017).

(alt. 1600-1800 m), Medeo-Mohnaja sopka in Almaty province, on dried twigs and stump of Sorbus

Ozom Kasl, Terskey Ala-Too range in the Tien-Shan Mountains, on dead wood of Picea schrenkiana,

6 Jun 1971, B. Kullman, TAAM 065201: Chatkal Mountain, Sary-Chelek Nature Reserve in Western

Kyrgyzstan, on dried stems and dead stump of Picea schrenkiana, 4 Aug 1967, A. \& T. Raitviir,

TAAM 044594; TAJIKISTAN: Pamir mountain range (Alt. 2700 m) in the northeast of Tajikistan, on

dead wood of Juniperus communis var. saxatilis Pall., 8 Jun 1978, I. Parmasto, TAAM 097334.

Records from Schwartsman (1964): KAZAKHSTAN: Dzungarian Alatau, Terekty-river valley,

Yablonevaya lesnaya dacha, 10 Jun 1944; Trans-Ili Alatau range, Maloe Almatinskoy ushelya, north slope of Moxnatoy copki (Alt 1700 m), 20 Oct 1946; pass of Butakovskiy (Alt. 2900 m) in North Tien Shan Mountains; Medeo, 10 Aug 1948; Saxroma 7 Aug 1948; river of Maloy Amatinka 17 Aug 1948; river Batareyki, 9 Aug 1948; Oliniy klyuv 17 Sep 1957; Issiqskoy, Lake Issyq, 1 Aug 1962; river 
238

Global distribution: AFRICA: Reunion Island (Riebesehl et al. 2015), South Africa (Hjortstam and Ryvarden 2007a); ASIA: Central Asia: Kazakhstan, Kyrgyzstan, Tajikistan; East Asia: China (Dai 2011), Japan, Taiwan (Langer 1994); South Asia: India (Kaur et al. 2014); EUROPE: all countries (Bernicchia and Gorjón 2010); NORTH AMERICA: Mexico (Tapia et al. 2016), USA (Gilbertson 1980); SOUTH AMERICA: Argentina (Greslebin and Rajchenberg 2000), Brazil (Hjortstam and Ryvarden 2009), Colombia (Hjortstam and Ryvarden 2008), Venezuela (Hjortstam and Ryvarden 2005); AUSTRALASIA: Australia, New South Wales (Langer 1994).

*Hyphodontia pallidula (Bres.) J. Erikss., Symb bot upsal 16 (1): 104, 1958.

Hyphodontia pallidula is morphologically close to H. alutaria, but differs in the smoother and more light-coloured basidiomata (Eriksson and Ryvarden 1976). Hyphodontia pallidula occurs on decaying coniferous wood of Picea forest in the Tien Shan Mountains of Kyrgyzstan. It can also be found on deciduous (Alnus, Betula, Populus) wood (Eriksson and Ryvarden 1976). The species occurs frequently in cold moist regions.

Specimens examined: KYRGYZSTAN: Issyk-Kul prov., Terskey Ala-Too (alt. $2100 \mathrm{~m}$ ) range in Western Tien Shan Mountains, Tochen kochae, on dead wood of Picea sp. 10 Apr 1971, B. Kullman, K. Kalamees \& A. Kollom, TAAM 009800.

Global distribution: AFRICA: South Africa (Hjortstam and Ryvarden 2007a); ASIA: Central Asia: Kyrgyzstan; East Asia: China (Dai 2011), Japan (Hjortstam and Ryvarden 2004), Taiwan (Wu 1990); South Asia: India (Kaur et al. 2014), Georgia (Ghobad-Nejhad and Hallenberg 2012); EUROPE: all countries (Bernicchia and Gorjón 2010); NORTH AMERICA: Canada, USA (Gilbertson 1980, Ginns 1998); SOUTH AMERICA: Venezuela (Hjortstam and Ryvarden 2005, 2007b), SOUTH ATLANTIC OCEAN: St. Helena (Ryvarden 2015).

Hyphodontia zhixiangii L.W. Zhou \& Yu. Sh. Gafforov, Phytotaxa, 299 (2): 273-279, 2017. 
This species was recently described on a living tree of Juniperus from Uzbekistan and is morphologically very close to Hyphodontia alutaria and $H$. arguta (Kan et al. 2017a). The current study found that $H$. zhixiangii also grows on Picea in Kazakhstan. Because only several specimens of H. zhixiangii have been studied from both morphological and phylogenetic perspectives, certain specimens collected from Central Asia and previously labelled as $H$. alutaria and $H$. arguta might actually represent $H$. zhixiangii. Future studies are helpful to check this hypothesis and get comprehensive knowledge of its distribution.

Specimens examined: KAZAKHSTAN: Northern Tien Shan Mountains, Trans-Ili Alatau range, Dzhonischke, Karascha, on stump of Picea schrenkiana, 16 May 1976, A. Raitviir, TAAM 063975.

Records from Kan et al. (2017a): UZBEKISTAN: Jizzakh Region, Zaamin District, Zaamin National Park, on the base of living Juniperus, 9 Sep 2016, L. W. Zhou, LWZ 20160909-4 (holotype in IFP, isotype in TASM), on stump of Juniperus, 9 Sep 2016, L. W. Zhou, LWZ 20160909-8, LWZ 20160909-9. (IFP, TASM).

Global distribution: ASIA: Central Asia: Kazakhstan (in this study), Uzbekistan (Kan et al. 2017a)

*Kneiffiella alutacea (Fr.) Jülich \& Stalpers, Verh K ned Akad Wet, tweede sect 74:134, 1980.

Among species of Hyphodontia s.l. with allantoid basidiospores and thin-walled, tubular cystidia, this is the only one with an odontioid hymenophore. However, there is great variation in the number and size of the thin-walled cystidia within species from different regions (Eriksson and Ryvarden 1976; Langer 1994). This is the first report of K. alutacea on Picea schrenkiana, from an area where the climate is generally moist, in mountain forest in the Northern Tien-Shan of Kazakhstan.

Specimens examined. KAZAKHSTAN: Almaty prov., Almatinka, Zailiysky Alatau Mountain range (elev. $2100 \mathrm{~m}$ ) in Northern Tien-Shan Mountains, on dead wood of Picea schrenkiana Fisch. \& C.A.Mey., 23 Aug 1963, A. Raitviir, TAAM 043393. 
287

288

289

290

291

292

293

294

295

296

297

298

299

300

301

302

303

304

305

306

307

308

309

310

Global distribution: ASIA: Central Asia: Kazakhstan; East Asia: China (Dai 2011), Japan (Hjortstam and Ryvarden 2004); South Asia: India (Kaur et al 2014); EUROPE: all countries (Eriksson and Ryvarden 1976; Langer 1994); NORTH AMERICA: Canada, USA (Gilbertson 1980); SOUTH AMERICA: Colombia (Hjortstam and Ryvarden 2008); SOUTH ATLANTIC OCEAN: St. Helena (Ryvarden 2015).

Kneiffiella floccosa (Bourdot \& Galzin) Jülich \& Stalpers, Verh K ned Akad Wet, tweede sect 74:130, 1980.

This rare species is reported on Picea schrenkiana from only a single specimen collected in 1949 at altitude 2286 m, in moist High Mountain coniferous forest of Trans-Ili Ala-Tau range in the Northern Tien Shan Mountain.

Record from Schwartsman (1964): KAZAKHSTAN: Almaty Prov., Northern Tien Shan Mountains, Trans-Ili Alatau mountain range (Alt. 2286 m), Lake Issyk, on dead wood of Picea schrenkiana, 25 Jun 1949.

Global distribution: ASIA: Central Asia: Kazakhstan; Eastern Asia: China (Dai 2011); EUROPE: Austria, Estonia, France, Sweden (Langer 1994); NORTH AMERICA: Canada, USA (Langer 1994).

*Lyomyces crustosus (Pers.) P. Karst., Revue mycol 3(9):23, 1881.

This common species has a wide distribution in the Northern Hemisphere and occurs both on deciduous and coniferous wood. Our specimens were collected in the desert shrublands to the high mountain forest, indicating that this species is well adapted to the arid and semi-arid environments of the study area. This is the first time L. crustosus has been found on dead stump and twigs of Crataegus azarolus var. pontica (K. Koch) K.I. Chr. and stump of Fraxinus pennsylvanica. We found many crystal encrustations on all specimens from arid and semi-arid regions of Central Asia. Strong crystal 
311 encrustations were previously reported (Langer 1994) in species growing in arid climates, mainly from 312 Lyomyces species.

313 Specimens examined: KYRGYZSTAN: Jalal-Abad prov., Chatkal Mountain, Sary-Chelek Nature 314 Reserve, on stump of Crataegus azarolus var. pontica, 04 Aug 1967, (TAAM 44593); 315 TURKMENISTAN: Kara-Kola district, Chozly-Deke (alt. 1250 m), on unknown deciduous wood, 22 316 April 1971, (TAAM 54961): UZBEKISTAN: Tashkent Prov., Bustonliq district, Oqtosh ximprom 317 oromgoxi (alt. $1350 \mathrm{~m}$ ), Ugam range in the Western Tien Shan Mountains, on living tree of Fraxinus 318 pennsylvanica Marshall., 03 Sep 2013, Yu. Sh. Gafforov, YG-G39 (TASM).

Global distribution: AFRICA: South Africa (Hjortstam and Ryvarden 2007a); ASIA: Central Asia:

Kyrgyzstan, Turkmenistan, Uzbekistan; East Asia: China (Dai 2011), Japan (Maekawa 1994), Taiwan

(Wu 1990); South Asia: India (Kaur et al. 2014); Armenia, Azerbaijan, Iran, Georgia (Ghobad-Nejhad

2011); EUROPE: many countries (Langer 1994); NORTH AMERICA: Mexico (Tapia et al. 2016),

USA (Ginns 1998); SOUTH AMERICA: Brazil (Hjortstam and Ryvarden 2009), Colombia (Hjortstam and Ryvarden 2007a), Venezuela (Hjortstam and Ryvarden 2005, 2007b); AUSTRALASIA: Australia (Maekawa 1994).

*Lyomyces erastii (Saaren. \& Kotir.) Hjortstam \& Ryvarden, Syn Fung 26:43, 2009. (Fig. 2) differs also in basidiospore size and shape. We collected L. erastii in a warm climatic xeric mountain 330 forest at altitude $1800 \mathrm{~m}$.

Specimens examined: UZBEKISTAN: Tashkent prov., Ugam-Chatkal National Natural State Park, 332 Xojikent village, Ugam range of Western Tien Shan Mountains, on deciduous wood, 2 Nov 2011, Yu. Sh. Gafforov, YG 022 (TASM). 
334

Global distribution: ASIA: Russia (Kotiranta and Saarenoksa 2000), Central Asia: Uzbekistan; Iran (Ghobad-Nejhad and Hallenberg 2012); EUROPE: Finland (Kotiranta and Saarenoksa 2000), Ukraine (Ordynets et al. 2012).

Lyomyces pruni (Lasch) Riebesehl \& E. Langer, Mycol Prog, 2017.

This species is widespread in continental areas from eastern Asia through Europe, as well as North and South America. It usually occurs in coniferous trees of the genera Abies, Cupressus and Juniperus, however species from the study site were reported on wood of deciduous Fraxinus (Schwartsman 1964). Morphologically L. pruni is close to the L. crustosus-group but it is distinguished by size, and spore of shape, also numerous subulate cystidiols in the hymenium.

Records from Schwartsman (1964): KAZAKHSTAN: Almaty Province, river Charyn in Northern Tien Shan Mountains, Charyn State National Natural Park, Ash forests, on dead wood of Fraxinus sp., 10 Mar 1943.

Global distribution: ASIA: Central Asia: Kazakhstan; East Asia: China (Dai 2011), Japan (Hjortstam and Ryvarden 2004), South Asia: India (Kaur et al. 2014); EUROPE: all countries (Langer 1994; Bernicchia and Gorjón 2010); NORTH AMERICA: Mexico (Tapia et al. 2016), USA (Ginns 1989); SOUTH AMERICA: Argentina (Greslebin and Rajchenberg 2000).

\section{*Lyomyces sambuci (Pers.) P. Karst., Bidr Känn Finl Nat Folk 37:153, 1882.}

This species is morphologically highly variable. It is widespread and common all over the world.

We found variation in size and number of the cystidia, as well as in size and shape of basidia and basidiospores among specimens from the study area, perhaps indicating that L. sambuci is a species complex rather than a homogenous taxon even within this region. Distribution of L. sambuci is known from the moist forest and subalpine forest in the high mountains of the northern European countries, and it extends as far as the xeric and shrublands forest-steppe from Tajikistan, Turkmenistan and 
359 Uzbekistan. Central Asian specimens are covered with many crystals, especially those from 360 Turkmenistan. The presence of numerous crystals may minimize evaporation of water in the arid and 361 semi-arid region. We report it for the first time on dead stem and stump of Populus pruinosa, 362 Philadelphus sp. and Acer turcomanicum from Central Asia.

363 Specimens examined: TAJIKISTAN: Khatlon prov., Tigrovaya Balka Nature Reserve (alt. 2000 m), 364 on stump of Populus pruinosa Schrenk, 31 March 1977, I. Parmasto, TAAM 096702; 365 TURKMENISTAN: Ashgabat Prov., Kopet -Dag basin, District Glok-Tepe, Dushak mountain (alt. 3662050 m), Geok-tepe District, on dead wood of Juniperus pseudosabina Fisch. \& C.A. Mey., 28 Oct 367 1971, E. Parmasto, TAAM 055650; Kopet - Dag mountain range (alt. 1700 m), Ahal Prov., Baharly 368 District, Arvaz, on dried stem of Acer turcomanicum Pojark., 18 October 1971, E. Parmasto, TAAM 369 055483; UZBEKISTAN: Botanical Garden in Tashkent city, on dead wood of Philadelphus sp., 20 April 1982, E. Parmasto, TAAM 104263; Botanical Garden in Tashkent city, on dead wood, 2 Sep 371 2013, Yu. Sh. Gafforov, YG-G2, YG-G8, YG-G20, YG-G31, YG-G33 (TASM); Tashkent Prov.,

Bustonliq District, Xojikent village, Ugam-Chatkal State National Natural Park, Ugam range of 373 Western Tien Shan Mountains, on dead wood branch, 14 October 2011, Yu. Sh. Gafforov, YG 036 374 (TASM).

Global distribution: ASIA: Central Asia: Tajikistan, Turkmenistan, Uzbekistan; East Asia: China 376 (Dai 2011), Taiwan (Wu 1990); South Asia: India (Kaur et al. 2014); EUROPE: all countries (Langer 1994; Bernicchia and Gorjón 2010); NORTH AMERICA: Mexico (Tapia et al. 2016), USA 378 (Gilbertson 1980; Ginns 1998); SOUTH AMERICA: Argentina (Greslebin and Rajchenberg 2000, 2003); AUSTRALASIA: Australia, New Zealand (Maekawa 1994); SOUTH ATLANTIC OCEAN: St. Helena (Ryvarden 2015).

Xylodon asperus (Fr.) Hjortstam \& Ryvarden, Syn Fung 26:34, 2009. 
383

In Central Asia, Xylodon asperus is known on deciduous trees of Populus talassica, endemic to Kazakhstan. This fungal species is distributed in temperate and tropical regions with cold and hot seasonable climate. So far, it has been collected temperate continental mountain region between 1700 $2300 \mathrm{~m}$ alt.

Records from Schwartsman (1964): KAZAKHSTAN: Almaty prov., Northern Tien Shan mountain, Trans-Ili Alatau range, Maloe Almatinskoy ushelya, Gorelnik u vodopada, 8 Aug 1948; Moxnatnoy sopki, 16 Aug 1948, "Vorota", 17 Aug 1948, Lake, 12 Jul 1956, Agroselxoz, 14 Aug 1948; Almaty Prov., River Charyn, 10 Mar 1943.

Global distribution: ASIA: Central Asia: Kazakhstan; East Asia: China (Dai 2011), Japan (Hjortstam and Ryvarden 2004); Armenia, Azerbaijan, Georgia, (Ghobad-Nejhad 2011); EUROPE: Norway, Sweden, Germany, Austria (Langer 1994); NORTH AMERICA: Mexico (Tapia et al. 2016), USA (Gilbertson 1980); SOUTH AMERICA: Colombia (Hjortstam and Ryvarden 2008), Venezuela (Langer 1994).

\section{Phylogenetic analysis}

The current dataset with 64 ITS sequences resulted in an alignment of 867 postions, including introduced gaps; 426 positions were constant. The data matrix is subdivided into the parts ITS1, 5.8S gene and ITS2 with the following positions: 1-385 for ITS1, 386-559 for 5.8S gene, 560-867 for ITS2.

Minimum evolution (ME) as well as Bayesian method generated congruent topologies in main lineages, and thus only the topology of ME analysis is presented with bootstrap (BS) values and integrated posterior probabilities from the Bayesian analysis. Phylogenetic analyses confirmed our morphological identifications of Hyphodontia zhixiangii, Lyomyces crustosus, L. erastii and L. sambuci (Fig. 3). 
408

409

410

411

412

413

414

415

416

417

418

419

420

421

422

423

424

425

426

427

428

429

430

431

432

433

434

435

436

437

438

\section{Key to species of Hyphodontia s. I. in Central Asia}

1. Cystidia emerging from subiculum........................................... 2

1. Cystidia emerging from subhymenium or hymenium ............... 3

2. Cystidia thin-walled

K. alutacea

2. Cystidia thick-walled

K. floccosa

3. Septocystidia and/or lagenocystidia present ........................... 4

3. Septocystidia and lagenocystidia absent 7

4. Spores $2.5-3 \mu \mathrm{m}$ wide. H. pallidula

4. Spores min. $3 \mu \mathrm{m}$ wide 5

5. Capitate/subcapitate cystidia or septocystidia basally

thick-walled 6

5. Capitate/subcapitate cystidia or septocystidia basally

thin-walled

.H. arguta

6. Spores $4.5-5 \times 3-3.5 \mu \mathrm{m}$ H. alutaria

6. Spores (4.3)4.6-5.5(6) × (3.2)3.3-4(4.3) $\mu \mathrm{m}$ H. zhixiangii

7. Cystidia fusiform with acute apex

L. crustosus

7. Cystidia with round apex 8

8. Hymenium smooth 9

8. Hymenium spiny 10

9. Hyphae of subiculum thick-walled .L. sambuci 9. Hyphae of subiculum thin-walled L. erastii 10. Hyphal ends of aculei tapering. L. pruni 10. Hyphal ends of aculei capitate $X$. asperus

\section{Re-identifications}

We have studied also three specimens collected in Turkmenistan and Uzbekistan by Erast Parmasto and Ain Raitviir in 1971 and 1972 that were labelled as "Hyphodontia sp.”, (TAAM 127581) or "Hyphodontia steccherinoides" (TAAM 134536, 134542). The latter name has never been published, and we consider it as ad interim name of Erast Parmasto. Our microscopic investigation showed that all three specimens represent Steccherinum ciliolatum (Berk. \& M.A. Curtis) Gilb. \& 
439 Budington. Three other specimens were named by the same collectors as "Hyphodontia pruni" 440 (TAAM 054973, 055024 and 054952). We re-identified these specimens as Hyphodermella rosae 441 (Bres.) Nakasone. All re-identifications were delivered to the TAAM herbarium via web-based 442 manager of biodiversity information PlutoF (Abarenkov et al. 2010, https://plutof.ut.ee).

\section{Geo-referencing data}

As a result of geo-referencing data from herbarium labels and literature information, and importing this data to ArcGIS 10.1 desktop, a distribution GIS map of Hyphodontia s.l. species in Central Asia was prepared (Fig. 1). Hyphodontia arguta was the most commonly collected species, found on coniferous and deciduous trees in moist mountain of Kazakhstan, Kyrgyzstan and Tajikistan. The next most abundant species was Lyomyces sambuci, distributed mainly in forest-steppe and xeric shrublands of Tajikistan, Turkmenistan and Uzbekistan. Lyomyces crustosus (on Crataegus azarolus var. pontica, Fraxinus pennsylvanica) and L. pruni (on Fraxinus sp.) occurred in the xeric mountains deciduous forest. Lyomyces erastii is collected in the warm climatic xeric mountain forest of Uzbekistan. Xylodon asperus, Kneiffiella alutacea, K. floccosa, Hyphodontia alutaria and H. pallidula were found only in the coniferous and deciduous forest trees in the mountains areas of Kazakhstan, Kyrgyzstan and Tajikistan. Most of the samples were collected from dead deciduous and coniferous wood showing a white rot.

457

458

\section{Discussion}

This preliminary survey of the diversity of corticioid white-rot fungi of Hyphodontia s.l. in Central 460 Asia reveals previously unreported species, as well as known species growing on previously unreported hosts. Hyphodontia alutaria, Lyomyces crustosus, L. erastii and L. sambuci are new for 
463

464

465

466

467

468

469

470

471

472

473

474

475

476

477

478

479

480

481

482

483

484

485

486

487

new for Tajikistan; H. arguta and H. pallidula are new for Kyrgyzstan; H. zhixiangii is new for Kazakhstan and Kneiffiella alutacea is reported as new record for Central Asia.

Our study of Hyphodontia s.1. diversity in Central Asia is a preliminary effort, but it suggests that much greater diversity of wood-rotting fungi than one might expect occur in this arid to semi-arid, largely treeless region. In a study examining a mere of 30 specimens from TAAM, and recently collected samples in Uzbekistan and from references, we report 11 species of Hyphodonia s.1., compared to only five reported previously (Schwartsman 1964; Eljchibayev 1966; Kan et al. 2017a). This study also expands the known hosts spectra for many of the Hyphodontia s.l. taxa studied. We expect that additional Hyphodontia s.1. species will be found in further mycological inventories (Kan et al. $2017 a)$

Increased sampling from other continents are needed to elucidate the taxonomy and diversity of these wide-ranging Hyphodontia s.l. species and other corticioid fungi from Central Asia. However, a more thorough examination of local specimens will also help to clarify the diversity. For example, Lyomyces pruni from Kazakhstan (Schwartsman 1964) examined here had basidiospores differing somewhat in size and shape compared to those growing further north. Either this extends the range of morphological variation in L. pruni, or it hints that more than one species is being called L. pruni. A more extensive study might find cryptic undescribed taxa in Central Asia when including more sequences for phylogenetic inference.

The incrustation with crystals on hyphae of Lyomyces crustosus, L. erastii and L. sambuci seems to be an adaption to their life-style on twigs and branches exposed to drought. Those species are very often found in areas with dry climatic conditions. This adaptation is to minimize water loss in the arid and semi-arid climate of Central Asia (Klein Tank et al. 2006).

Our phylogenetic study reveals our collections of three species (L. erastii, L. crustosus and $H$. zhixiangii) to be conspecific with representative of these species from other regions, thus confirming their identifications. Three sequences from our L. sambuci specimens YG 036, YG-G2 and TAAM 
488

489

490

491

492

493

494

495

496

497

498

499

500

501

502

503

504

505

506

507

508

509

510

511

104263 clustered with high support with another L. sambuci sequence (TFC Mic 15133) from Spain. It is striking that a further sequence of L. sambuci with its origin in Taiwan (GEL3400) does not fit into this clade. But nevertheless this sequence is closely orientated to the L. sambuci cluster with our sequences. Eriksson and Ryvarden (1976) assumed on morphological basis that L. sambuci represents a species complex. The differences between the sequences from specimens from Taiwan and Spain/Uzbekistan support this theory. Therefore, Uzbekistan L. sambuci collections are conspecific with European specimens. Consequently, a further morphological study is needed to clarify if the Taiwanese material belongs to an independent species.

\section{Acknowledgements}

This work was supported by Committee for coordination science and technology development under the Cabinet of Ministers of Uzbekistan (Project No. P3-2014-0830174425) and National Natural Science Foundation of China (Project No. 31570014), Youth Innovation Promotion Association CAS (No. 2017240) and German Academic Exchange Service (DAAD) for a visiting fellowship of the first author A/13/03723; TWAS-CNPq postdoctoral fellowship 190136/2013-8. Authors thank warmly TAAM curator Dr. Ilmy Parmasto for issuing a permission and technical help while studying herbarium specimens at the Estonian University of Life Sciences Tartu, Estonia. The first author thanks Dr. Indrek Sell (Estonia) for organizing trip to TAAM herbarium. We are thankful to Drs. Barbara Wilson and Amy Rossman (Corvallis, Oregon) for reviewing and valuable comments of the earlier manuscript version. We thank Ms Yu Zhou (Worcester, Massachusetts) for assistance with GIS mapping.

\section{References}

Abarenkov, K., Tedersoo, L., Nilsson R.H., Vellak, K., Saar, I., Veldre, V., Parmasto, E., Prous, M., Aan, A., Ots, M., Kurina, O., Ostonen, I., Jõgeva, J., Halapuu, S., Põldmaa, K., Toots, M., Truu, J., Larsson, K.H, 
512

513

514

515

516

517

518

519

520

521

522

523

524

525

526

527

528

529

530

531

532

533

534

535

536

537

and Kõljalg, U. 2010. PlutoF-a web based workbench for ecological and taxonomic research, with an online implementation for fungal ITS sequences. Evol. Bioinf. 6: 189-196. doi: 10.4137/EBO.S6271.

Ariyawansa, H.A., Hyde, K.D., Jayasiri, S.C., Buyck, B., Chethana, K.W.T., Dai, D.Q., Dai, Y.C., Daranagama, D.A., Jayawardena, R.S., Lücking, R., Ghobad-nejhad, M., Niskanen, T.,Thambugala, K.M., Voigt, K., Zhao, R.L., Li, G.J., Doilom, M., Boonmee, S., Yang, Z.L., Cai, Q., Cui, Y.Y., Bahkali, A.H., Chen, J., Cui, B.K., Chen, J. J., Dayarathne, M.C., Dissanayake, A.J., Ekanayaka, A.H., Hashimoto, A., Hongsanan, S., Jones, E.B.G., Larsson, E., Li, W.Jing., Li, Q.R., Liu, J.K., Luo, Zong L., Maharachchikumbura, S.S.N., Mapook, A., Mckenzie, E.H.C., Norphanphoun, C., Konta, S., Pang, K.L., Perera, R.H., Phookamsak, R., Phukhamsakda, C., Pinruan, U., Randrianjohany, E., Singtripop, C., Tanaka, K., Tian, C.M., Tibpromma, S., Abdel-wahab, M.A., Wanasinghe, D.N., Wijayawardene, N.N., Zhang, J.F., Zhang, H., Abdel-aziz, F.A., Wedin, M., Westberg, M., Ammirati, J.F., Bulgakov, T.S., Lima, D.X., Callaghan, A., Callac, P., Chang, C., Coca, L.F., Dal-forno, M., Dollhofer, V., Fliegerová, K., Greiner, K., Griffith, G.W., Ho, H., Hofstetter, V., Jeewon, R., Kang, J.C., Kirk, P.M., Kytövuori, I., Lawrey, D., Xing, J., Li, H., Liu, Z.Y., Liu, X.Z., Liimatainen, K., Lumbsch, H.T., Matsumura, M., Moncada, B., Nuankaew, S., Parnmen, S., De Azevedo Santiago, A.L.C.M., Sommai, S., Song, Y., De Souza, C.A.F., De Souza-motta, C.M., Su, H.Y., Suetrong, S., Wang, Y., Wei, S.F., Wen, T.C., Yuan, H.S., Zhou, L.W., Réblová, M., Fournier, J., Camporesi, E., Luangsa-ard, J. J., Tasanathai, K., Khonsanit, A., Thanakitpipattana, D., Somrithipol, S., Diederich, P., Millanes, A.M., Common, R.S., Stadler, ., Yan, J.Y., Li, X.H., Lee, H.W., Nguyen, T.T. T., Lee, H.B., Battistin, E., Marsico, O., Vizzini, A., Vila, J., Ercole, E., Eberhardt, U., Simonini, G., Wen, H.A., Chen, X.H., Miettinen, O., and Spirin, V. 2015. Fungal diversity notes 111-252 - taxonomic and phylogenetic contributions to fungal taxa. Fungal Diversity, 75(1): 27-274. doi: 10.1007/s13225-015-0346-5.

Bernicchia, A., and Gorjón, S.P. 2010. Corticiaceae s.1. Fungi Europaei 12. Candusso Edizioni, Press, Italy Chen, J.J., Zhou, L.W., Ji, X.H., and Zaho, C.L. 2016. Hyphodontia dimitica and H. subefibulata spp. nov. (Schizoporaceae, Hymenochaetales) from southern China based on morphological and molecular characters. Phytotaxa, 269(1): 001-013 doi.org/10.11646/phytotaxa.269.1.1. 
538 Chen, C.C., Wu, S.H., and Chen, C.Y. 2017. Three new species of Hyphodontia s.1. (Basidiomycota) with 539 poroid or raduloid hymenophore. Mycol. Prog. 16(5): 553-564. doi: 10.1007/s11557-017-1286-0.

540 Cunningham, G.H. 1963. The Thelephoraceae of Australia and New Zealand. New Zealand Dept. Sci. Ind. Res. $541 \quad$ Bull. 145: 1-359.

542 Dai, Y.C. 2011. A revised checklist of corticioid and hydnoid fungi in China for 2010. Mycoscience, 52: 69-79. 543 doi:10.1007/s10267-010-0068-1.

544 Dai, Y.C. 2012. Polypore diversity in China with an annotated checklist of Chinese polypores. Mycoscience, 53 : 545 49-80. DOI: $10.1007 / \mathrm{s} 10267-011-0134-3$.

546 Dueñas, M., Telleria, M.T., Melo, I., and Martín, M.P. 2009. Lagarobasidium calongei (Aphyllophorales, 547 Basidiomycota), a new species of corticioid fungi from Azore Islands. Anales Jard. Bot. Madrid, 66(S1): $548 \quad$ 41-46. doi: 10.3989/ajbm.2230.

549 Eljchibayev, A.A. 1969. On macromycetes flora of Central Tien-shan. Micol. Fitopatol. 3: 38-43. (In Russian). 550 Eriksson, J., and Ryvarden, L. 1976. The Corticiaceae of North Europe 4: Hyphodermella - Mycoacia. $551 \quad$ Fungiflora Press, Oslo.

552 Fukami, T., Dickie, I.A., Paula Wilkie, J., Paulus B.C., Park, D., Roberts, A., Buchanan, P.K., and Allen, R.B. 553 2010. Assembly history dictates ecosystem functioning: evidence from wood decomposer communities. $554 \quad$ Ecol. Lett. 13(6):675-684. doi: 10.1111/j.1461-0248.2010.01465.x.

555 Gafforov, Y., Tomšovský, M., Langer, E., and Zhou, L.W. 2014. Phylloporia yuchengii sp. nov. 556 (Hymenochaetales, Basidiomycota) from Western Tien Shan Mountains of Uzbekistan based on 557 phylogeny and morphology. Cryptogam. $313-322$. $558 \quad$ doi.org/10.7872/crym.v35.iss4.2014.313.

559 Gardes, M., and Bruns, T.D. 1993. ITS primers with enhanced specificity for basidiomycetes - application to 560 the identification of mycorrhizae and rusts. Mol. Ecol. 2(2): 113-118.

561 Ghobad-Nejhad, M. 2011. Updated checklist of corticioid and poroid basidiomycetes of the Caucasus region. $562 \quad$ Mycotaxon, 117: 508.

563 Ghobad-Nejhad, M., and Hallenberg, N. 2012. Checklist of Iranian non-gilled/non-gasteroid hymenomycetes 564 (Agaricomycotina). Mycotaxon, 119: 494. 
565 Gilbertson, R.L. 1980. Wood-rotting fungi of North America. Mycologia, 72(1): 1-49. doi: 10.2307/3759417.

566 Ginns, J., and Lefebvre, M.N.L. 1993. Lignicolous corticioid fungi (Basidiomycota) of North America.

567 Systematics, distribution, and ecology. Mycol. Mem. 19: 1-247.

568 Ginns, J.H. 1989. Descriptions and notes for some unusual North American corticioid fungi (Aphyllophorales, 569 Corticiaceae). Memoirs of the New York Botanical Garden, 49: 129-137.

570 Ginns, J. 1998. Genera of the North American Corticiaceae s. 1. Mycologia, 90(1): 1-35. doi:10.2307/3761008

571 Gorjón, S.P. 2012. Some species of Hyphodontia s.l. with encrusted cystidial elements. Mycosphere 3(4): 464572 474. doi:10.5943/mycosphere/3/4/10.

573 Greslebin, A.G., and Rajchenberg, M. 2000. The genus Hyphodontia in the Patagonian Andes forests of 574 Argentina. Mycologia, 92(6): 1155-1165. doi:10.2307/3761483.

575 Greslebin, A.G., and Rajchenberg, M. 2003. Diversity of Corticiaceae s. 1. in Patagonia, Southern Argentina. 576 N.Z. J. Bot. 41(3): 437-446. doi:10.1080/0028825X.2003.9512861.

577 Hawksworth, D.L., Kirk, P.M., Sutton, B.C., and Pegler, D.N. 1995. Ainsworth\& Bisby's Dictionary of the 578 Fungi. 8th ed.: - CABI Publ., Wallingford.

579 Hibbett, D.S., Binder, M., Bischoff, J.F., Blackwell, M., Cannon, P.F., Eriksson, E., Huhndorf, O.S., James, T., 580 Kirk, P.M., Lücking, R., Thorsten Lumbsch, H., Lutzoni, F., Matheny, P.B., McLaughlin, D.J., Powell, 581 M.J., Redhead, S., Schoch, C.L., Spatafora, J.W., Stalpers, J.A., Vilgalys, R., Aime, M.C., Aptroot, A., 582 Bauer, R., Begerow, D., Benny, G.L., Castlebury, L.A., Crous, P.W., Dai, Y.C., Gams, W., Geiser, D.M., 583 Griffith, G.W., Gueidan, C., Hawksworth, D.L., Hestmark, G., Hosaka, K., Humber, R.A., Hyde, K.D., 584 Ironside, J.E,, Kõljalg, U., Kurtzman, C.P., Larsson, K.H., Lichtwardt, R., Longcore, J., Miadlikowska, J., 585 Miller, A., Moncalvo, J.M., Standridge, S.M., Oberwinkler, F., Parmasto, E., Reeb, V., Rogers, J.D., 586 Roux, C., Ryvarden, L., Sampaio, J.P., Schübler, A., Sugiyama, J., Thorn, R.G., Tibell, L., Untereiner, 587 588 W.A., Walker, C., Wang, Z., Weir, A., Weiss, M., White, M,M., Winka, K., Yao, Y.J., and Zhang, N. 2007. A higher-level phylogenetic classification of the Fungi. Mycol. Res. 111: 509-547 doi:10.1016/j.mycres.2007.03.004.

Hjortstam, K. 1983. Studies in the genus Hyphodontia (Basidiomycetes) I. Hyphodontia John Erikss. sectio Hyphodontia. Mycotaxon, 17: 550-554. 
592 Hjortstam, K., and Ryvarden, L. 2004. Some new and noteworthy corticioid fungi (Basidiomycotina, 593 Aphyllophorales) from Japan. Synopsis Fungorum, 18: 8-13.

594 Hjortstam, K., Ryvarden, L., and Iturriaga, T. 2005. Studies in corticioid fungi from Venezuela II 595 (Basidiomycotina, Aphyllophorales). Synopsis Fungorum, 20: 42-78.

596

597

Hjortstam, K., and Ryvarden, L. 2007a. Checklist of corticioid fungi (Basidiomycotina) from the tropics, 598 subtropics, and the southern hemisphere. Synopsis Fungorum, 22: 27-146.

Hjortstam, K., and Ryvarden, L. 2007b. Studies corticioid fungi from Venezuela III (Basidiomycotina, 599 Aphyllophorales). Synopsis Fungorum, 23: 56-111.

600 601

Hjortstam, K., and Ryvarden, L. 2008. Corticioid species (Basidiomycotina, Aphyllophorales) from Colombia 602 IV. Synopsis Fungorum, 25: 28-37.

Hjortstam, K., and Ryvarden, L. 2009. A checklist of names in Hyphodontia sensu stricto - sensu lato and 603 604 Schizopora with new combinations in Lagarobasidium, Lyomyces, Kneiffiella, Schizopora, and Xylodon. 605 606 607 Synopsis Fungorum, 26:33-55.

Jang, Y.S., Jang, S.Y., Lee, J.J., Lee, H., Lim, Y.W., Kim, C.M., and Kim, J.J. 2016. Diversity of woodinhabiting polyporoid and corticioid fungi in Odaesan National Park, Korea. Mycobiology, 44(4): $217-$ 236. doi:10.5941/MYCO.2016.44.4.217.

608 609

Kan, Y.H., Gafforov, Y., Li, T. and Zhou, L.W. 2017a. Hyphodontia zhixiangii sp. nov. (Schizoporaceae, Basidiomycota) from Uzbekistan. Phytotaxa, 299(2): 273-279. doi: 10.11646/phytotaxa.299.2.12.

Kan, Y.H., Qin, W.M., and Zhou, L.W. 2017b. Hyphodontia mollissima sp. nov. (Schizoporaceae, Hymenochaetales) from Hainan, southern China. Mycoscience, 58(4): 297-301. doi: 10.1016/j.myc.2017.04.003.

Katoh, K., and Standley, D.M. 2013. MAFFT multiple sequence alignment software version 7: improvements in performance and usability. Mol. Biol. Evol. 30(4): 772-780. doi.org/10.1093/molbev/mst010.

Kaur, M., Singh, A.P., and Dhingra, G.S. 2014. Genus Hyphodontia J. Erikss. in district Shimla (Himachal Pradesh). Kavaka 43: 70-73.

Kirk, P.M., Cannon, P.F., Minter, D.W., and Stalpers, J.A. 2008. Dictionary of the Fungi. 10th ed.: - CABI Publ., Wallingford. 
619 Klein Tank, A.M.G., Peterson, T.C., Quadir, D.A., Dorji, S., Zou, X., Tang, H., Santhosh, K., Joshi, U.R.,

620

621

622

623

624

625

626

627

628

629

630

631

632

633

634

635

636

637

638

639

640

641

642

643 Jaswal, A.K., Kolli, R.K., Sikder, A., Deshpande, N.R., Revadekar, J.V., Yeleuova, K., Vandasheva, S., Faleyeva, M., Gomboluudev, P., Budhathoki, K.P., Hussain, A., Afzaal, M., Chandrapala, L., Anvar, H., Amanmurad, D., Asanova, V.S., Jones, P.D., New, M.G., and Spektorman, T. 2006. Changes in daily temperature and precipitation extremes in central and south Asia. J. Geophys. Res. 111(D16): doi: 10.1029/2005JD006316.

Kotiranta, H., and Saarenoksa, R. 2000. Three new species of Hyphodontia (Corticiaceae). Ann. Bot. Fenn. 37(4): 255-278. http://www.jstor.org/stable/23726673.

Kumar, S., Stecher, G., and Tamura, K. 2016. MEGA7: Molecular Evolutionary Genetics Analysis version 7.0. Mol. Biol. Evol. 33(7): 1870-1874. doi:10.1093/molbev/msw054

Langer, E. 1994. Die Gattung Hyphodontia John Eriksson. Bibliotheca Mycologica 154. J. Gramer Press. Berlin-Stuttgart.

Langer, E. 1998. Evolution of Hyphodontia (Corticiaceae, Basidiomycetes) and related Aphyllophorales inferred from ribosomal DNA sequences. Folia Cryptogamica Estonica, 33: 57-62.

Langer, E., and Dai, Y.C. 1998. Changbai wood-rotting fungi 8. Hyphodontia syringae sp. nov. Mycotaxon, 67: $181-190$.

Largent, D.L,, Johnson, D., Watling, R., and Simson K., 1977. How to Identify Mushrooms to Genus III. Microscopic Features. Mad River Press, Eureka.

Larsson, K.H., Parmasto, E., Fischer, M., Langer, E., Nakasone, K.K., and Redhead, S.A. 2006. Hymenochaetales: a molecular phylogeny for the hymenochaetoid clade. Mycologia, 98(6): 926-936. doi.org/10.1080/15572536.2006.11832622.

Larsson, K.H. 2007. Re-thinking the classification of corticioid fungi. Mycol. Res. 111(9): 1040-1063. doi: 10.1016/j.mycres.2007.08.001.

Lee, I.S., and Langer, E. 2012. New records of Hyphodontia species from Taiwan. Nova Hedwigia, 94(1-2): 239-244. doi:10.1127/0029-5035/2012/0094-0239. 
644 Lioubimtseva, A.E., and Henebry, G.M. 2009. Climate and environmental change in arid Central Asia: Impacts, 645 vulnerability, and adaptations. J. Arid Environ. 73(11): 963-977. doi.org/10.1016/j.jaridenv.2009.04.022. 646 Maekawa, N. 1993. Taxonomic study of Japanese Corticiaceae (Aphyllophorales) 1. Rep. Tottori Mycol. Inst. 647 31: $1-149$.

648 Maekawa, N. 1994. Taxonomic study of Japanese Corticiaceae (Aphyllophorales) 2. Rep. Tottori Mycol. Inst. $649 \quad 32: 1-123$.

650 651

Maekawa, N. 2000. Taxonomic study of Japanese Corticiaceae (Aphyllophorales) 6. Rep. Tottori Mycol. Inst.

652 Naturalearthdata. 2017. http://www.naturalearthdata.com/.

653 Olson, D.M., Dinerstein, E., Wikramanayake, E.D., Burgess, N.D., Powell, G.V.N., Underwood, E.C., D’amico, 654 J.A., Itoua, I., Strand, H.E., Morrison, J.C., Loucks, C.J., Allnutt, T.F., Ricketts, T.H., Kura, Y., 655 Lamoreux, J.F., Wettengel, W.W., Hedao, P., and Kassem, K.R. 2001. Terrestrial ecoregions of the world: 656 BioScience, 51(11): 933-938. doi.org/10.1641/0006-3568(2001)051[0933:TEOTWA]2.0.CO;2.

Ordynets, O., Akulov, O., and Shyian-Hlotova, H. 2012. Aphyllophoroid fungi of Stanychno-Luhanske division of Luhansk Nature Reserve. Nature reserves in Ukraine, 17(1-2): 28-33. (In Ukrainian with English summary).

Parmasto, E. 1968. Conspectus Systematis Corticiacearum. Institutum Zoologicum et Botanicum Academiae Scientiarum R.P.S.S. Estonicae PressTartu.

Paulus, B., Hallenberg, N., Buchanan, P.K., and Chambers, G.K. 2000. A phylogenetic study of the genus Schizopora (Basidiomycota) based on ITS DNA sequences. Mycol. Res. 104(10): 1155-1163.

665 doi.org/10.1017/S0953756200002720.

666

Petersen, J.H. 1996. Farvekort. The Danish Mycological Society's colour-chart. Foreningen til

667 Rambaut, A. 2012. FigTree v1.4. http://tree.bio.ed.ac.uk/software/figtree. Accessed 5 December 2012.

668 Riebesehl, J., Langer, E.J., Ordynets, A., Striegel, M.M., and Witzany, C. 2015. Hyphodontia borbonica, a new 669 species from La Réunion. Mycol. Prog. 14(104): 1-7 DOI 10.1007/s11557-015-1126-z.

670 Riebesehl, J., and Langer, E. 2017. Hyphodontia s.1. (Hymenochaetales, Basidiomycota): 35 new combinations 
671

672

673

674

675

676

677

678

679

680

681

682

683

684

685

686

687

688

689

690

691

692

693

694

695

696

and new keys to all 120 current species. Mycol. Prog. 16(6): 637-666. doi: 10.1007/s11557-017-1299-8.

Ronquist, F., and Huelsenbeck, J.P. 2003. MrBayes 3: Bayesian phylogenetic inference under mixed models. Bioinformatics, 19: 1572-1574.http://dx.doi.org/10.1093/bioinformatics/btg180.

Rosenthal, L.M., Larsson, K.H., Branco, S., Chung, J.A., Glassman, S.I., Liao, H.L., Peay, K.G., Smith, D.P., Talbot, J.M., Taylor, J.W., Vellinga, E.C., Vilgalys, R., and Bruns, T.D. 2017. Survey of corticioid fungi in North American pinaceous forests reveals hyperdiversity, underpopulated sequence databases, and species that are potentially ectomycorrhizal. Mycologia, 109(1): 115-127. doi: $10.1080 / 00275514.2017 .1281677$.

Ryvarden, L. 2015. Notes on Homobasidiomycetes from St. Helena. Synopsis Fungorum, 33: 20-24.

Schwartsman, S.R. 1964. Flora Sporowich Rastenii Kazachstana, Tom. IV: Auriculariales, Tremellales, Dacryomycetales, Exobasidiales, Aphyllophorales. Nauka Press, Alma Ata (In Russian).

Swift, M.J. 1982. Basidiomycetes as components of forest ecosystems. In: Decomposer Basidiomycetes, their biology and ecology. (Edited by J.C. Frankland, J.N. Hedger, and M.J. Swift). Cambridge University Press. Cambridge.

Tapia, F., Chacón, S., and Gorjón, S.P. 2016. Hongos corticioides (Agaricomycetes) citados de México. Acta Bot. Mex. 114:15-50.

ThePlantList. 2013. Version 1.1. Published on the Internet; http://www.theplantlist.org/ (accessed November 2015).

Thiers, B. 2016. [continuously updated]. Index Herbariorum: A global directory of public herbaria and associated staff. New York Botanical Garden's Virtual Herbarium. http://sweetgum.nybg.org/science/ih/.

Wang, Y., Lai, Z., Li, X.X., Yan, R.M., Zhang, Z.B., Yang, H.L., and Zhu, D. 2016. Isolation, diversity and acetylcholinesterase inhibitory activity of the culturable endophytic fungi harboured in Huperzia serrata from Jinggang Mountain, China. World J. Microb. Biot. 32(2):1-23.

White, T.J., Bruns, T.D., Lee, S., Taylor, J. 1990. Amplification and direct sequencing of fungal ribosomal RNA genes for phylogenetics. In PCR protocols: A guide to methods and applications. Edited by M.A. Innis and D.H. Gelfand. London: Academic Press. pp. 315-322. 
697 Wu, S.H. 1990. The Corticiaceae (Basidiomycetes) subfamilies Phlebioideae, Phanerochaetoideae and 698 Hyphodermoideae in Taiwan. Ann. Bot. Fenn. 142: 1-123.

699 Wu, S.H. 2001. Three new species of Hyphodontia with poroid hymenial surface. Mycologia, 93(5): 1019$700 \quad$ 1025. doi:10.2307/3761766.

701 Wu, S.H. 2006. Hyphodontia tubuliformis, a new species from Taiwan. Mycotaxon, 95: 185-188.

702 Xiong, H.X., Dai, Y.C., and Wu, S.H. 2009.Three new species of Hyphodontia from Taiwan. Mycol. Prog. 8(3): 703 165-169. doi:10.1007/s11557-009-0587-3.

704 Xiong, H.X., Dai, Y.C., and Wu, S.H. 2010. Two new species of Hyphodontia from China. Mycologia, 102(4): 705 918-922. doi.org/10.3852/09-139.

706 Yombiyeni, P., Douanla-Meli, C., Amalfi, M., and Decock, C. 2011. Poroid Hymenochaetaceae from Guineo707 Congolian rainforest: Phellinus gabonensis sp. nov. from Gabon-taxonomy and phylogenetic 708 relationships. Mycol. Prog. 10(3): 351-362. doi:10.1007/s11557-010-0708-z.

709 Yurchenko, E., and Wu, S.H. 2013. Four new species of Hyphodontia (Xylodon s.s. Hjortstam and Ryvarden, 710 Basidiomycota) from Taiwan. Nowa Hedwigia, 96: 545-558. doi:10.1127/0029-5035/2013/0092.

711 Yurchenko, E., and Wu, S.H. 2014. Three new species of Hyphodontia with peg-like hyphal aggregations. 712 Mycol. Prog. 13(3): 533-545. doi: 10.1007/s11557-013-0935-1.

713 Yurchenko, E., and Wu, S.H. 2016. A key to the species of Hyphodontia sensu lato. MycoKeys, 12: 1-27. 714 doi.org/10.3897/mycokeys.12.7568.

715 Zhao, C.L., Cui, B.K., and Dai, Y.C. 2014. Morphological and molecular identification of two new species of 716 Hyphodontia (Schizoporaceae, Hymenochaetales) from southern China. Cryptogam. Mycol. 35(1): 87-97. 717 doi:10.7872/crym.v35.iss 1.2014.87.

718 Zhou, Y., Zhang, L., Fensholt, R., Wang, K., Vitkovskaya, I., and Tian, F. 2015. Climate contributions to 719 vegetation variations in central Asian drylands: Pre-and post-USSR collapse. Remote Sensing, 7(3): 24492470. doi:10.3390/rs 70302449 . 
724 Fig. 1 Distribution map of Hyphodontia s.l. species in Central Asia

725 Fig. 2 Lyomyces erastii, YG 022 (TASM)

726 Fig. 3 Phylogenetic position of Central Asian species of Hyphodontia s.l. sequenced in this study. The topology

727 was inferred using the Minimum Evolution method on the basis of ITS dataset. Bootstrap values are shown

728 below the branches and Bayesian posterior probabilities above the branches. Names of specimens with 729 sequences obtained in this study are given in bold.

730

731 


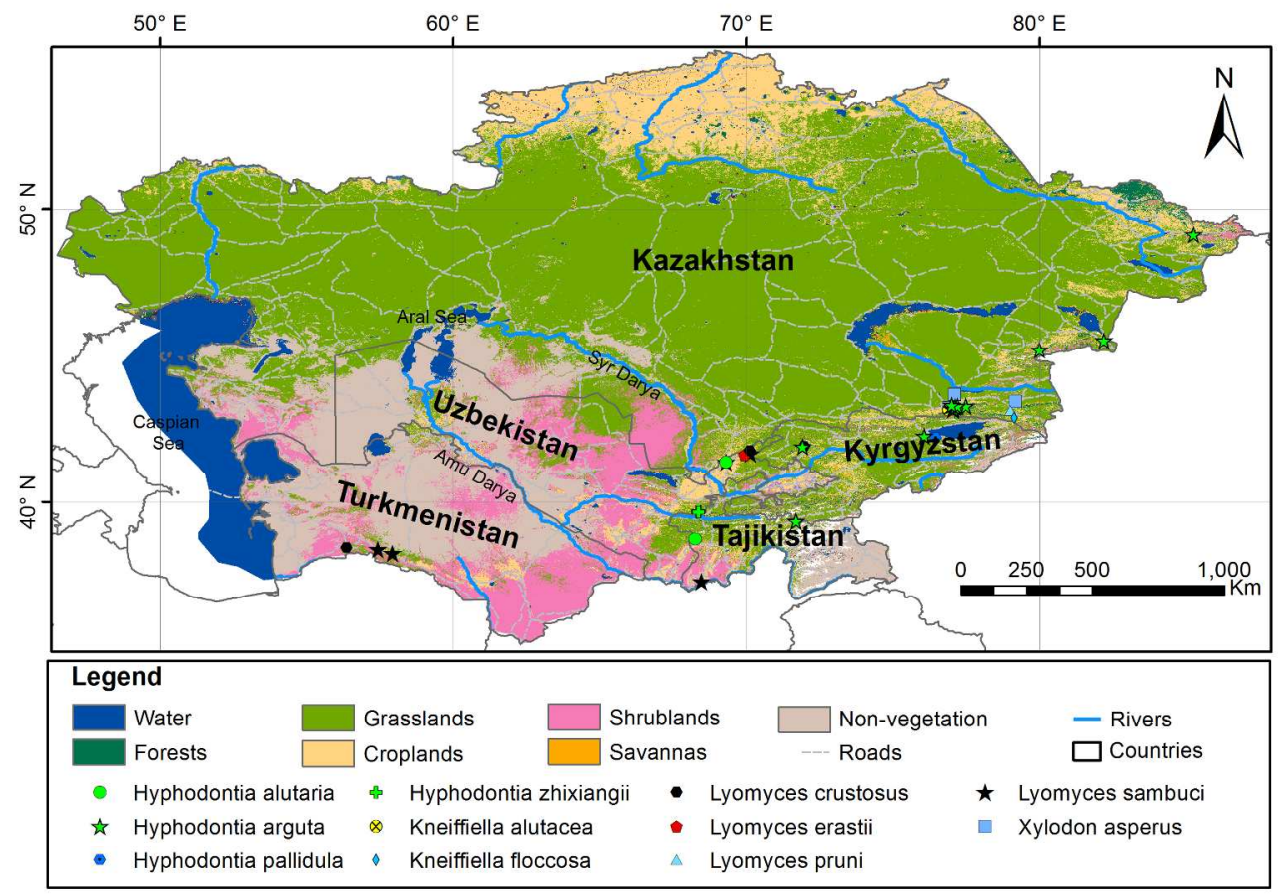

Fig. 1 Distribution map of Hyphodontia s.I. species in Central Asia $249 \times 189 \mathrm{~mm}(300 \times 300 \mathrm{DPI})$ 


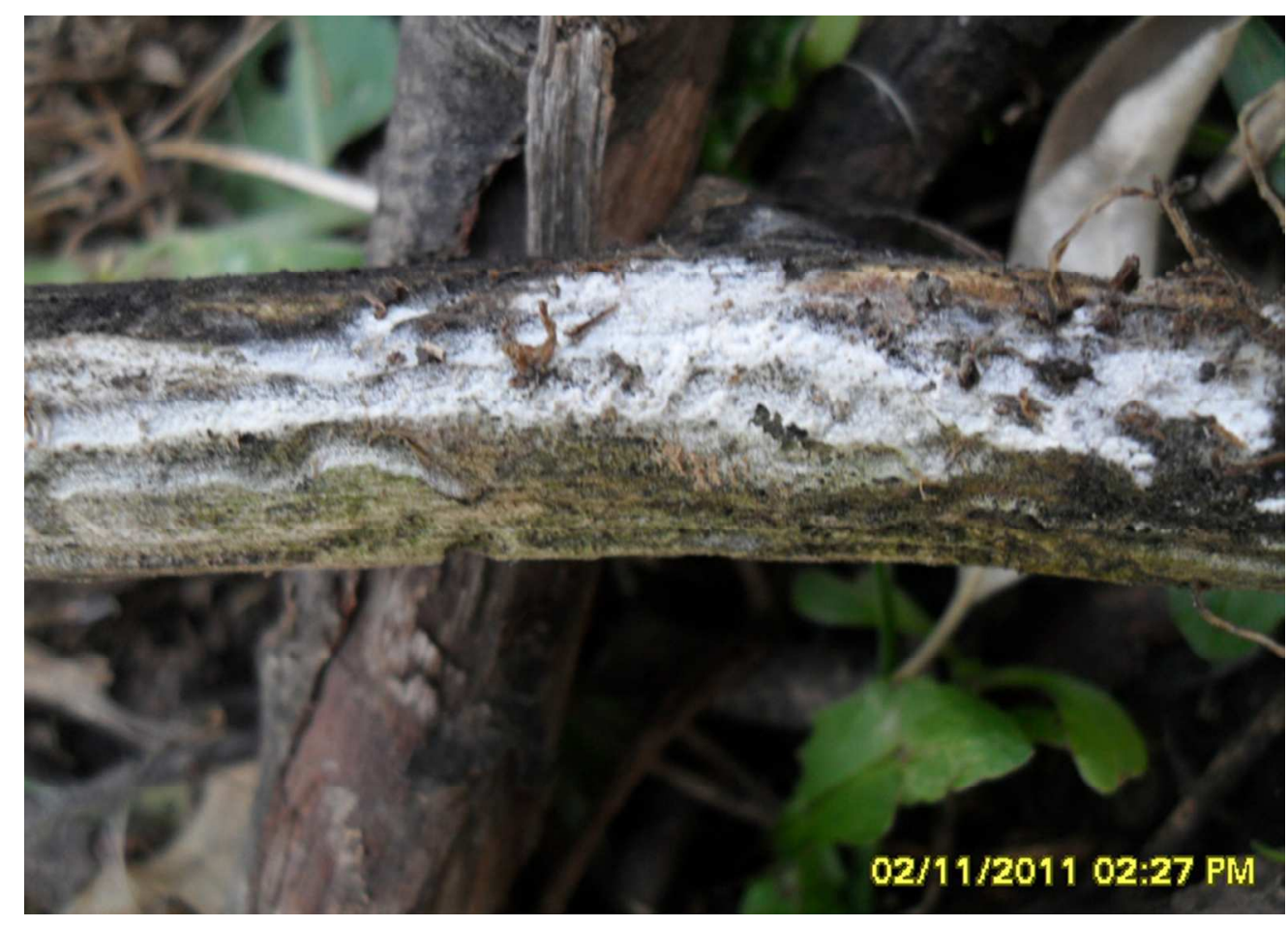

Fig. 2 Lyomyces erastii, YG 022 (TASM)

$92 \times 66 \mathrm{~mm}(300 \times 300 \mathrm{DPI})$ 


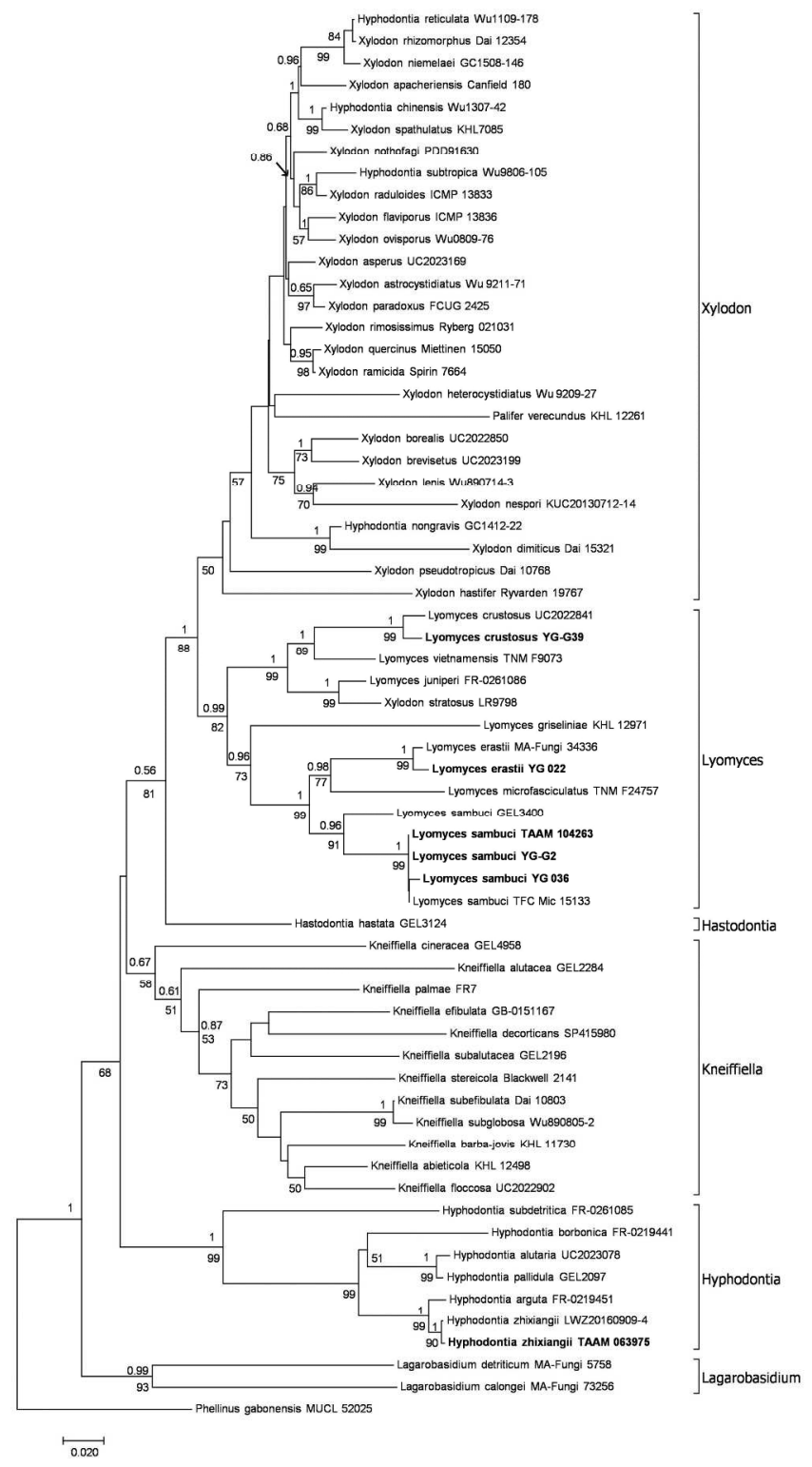

Fig. 3 Phylogenetic position of Central Asian species of Hyphodontia s.I. sequenced in this study. The topology was inferred using the Minimum Evolution method on the basis of ITS dataset. Bootstrap values are shown below the branches and Bayesian posterior probabilities above the branches. Names of specimens with sequences obtained in this study are given in bold.

$184 \times 286 \mathrm{~mm}(300 \times 300 \mathrm{DPI})$ 
Table 1. Specimens used for the phylogenetic analyses. Sequences generated in this study are given in bold.

\begin{tabular}{|c|c|c|c|c|}
\hline \multirow{3}{*}{ Species } & \multirow{3}{*}{ Specimen voucher } & GenBank & \multirow{3}{*}{ Reference } & \multirow{3}{*}{ Origin } \\
\hline & & accession number & & \\
\hline & & ITS & & \\
\hline Hastodontia hastata (Litsch.) Hjortstam \& Ryvarden & KAS-GEL3124 & DQ340311 & unpublished & Sweden \\
\hline Hyphodontia alutaria (Burt) J. Erikss. & UC2023078 & KP814431 & Rosenthal et al. 2017 & USA \\
\hline H. $\operatorname{arguta}(\mathrm{Fr}$.$) J. Erikss.$ & FR-0219451 & KR349243 & Riebesehl et al. 2015 & La Réunion \\
\hline H. borbonica Riebesehl, E. Langer \& Barniske & FR-0219441 & KR349240 & Riebesehl et al. 2015 & La Réunion \\
\hline H. chinensis C.C. Chen \& Sheng H. Wu & Wu1307-42 & KX857802 & Chen et al. 2017 & China \\
\hline H. nongravis (Lloyd) Sheng H. Wu & GC1412-22 & KX857801 & Chen et al. 2017 & Taiwan \\
\hline H. pallidula (Bres.) J. Erikss. & KAS-GEL2097 & DQ340317 & unpublished & Germany \\
\hline H. reticulata C.C. Chen \& Sheng H. Wu & Wu1109-178 & KX857805 & Chen et al. 2017 & Taiwan \\
\hline H. subdetritica S.S. Rattan & FR-0261085 & KY081793 & Riebesehl \& Langer 2017 & La Réunion \\
\hline H. subtropica C.C. Chen \& Sheng H. Wu & Wu9806-105 & KX857807 & Chen et al. 2017 & Vietnam \\
\hline H. zhixiangii L.W. Zhou \& Yu.Sh. Gafforov & TAAM 063975 & MF382994 & This study & Kazakhstan \\
\hline H. zhixiangii & LWZ20160909-4 & KY440396 & Kan et al 2017a & Uzbekistan \\
\hline Kneiffiella abieticola (Bourdot \& Galzin) Jülich \& Stalpers & KHL 12498 (GB) & DQ873601 & Larsson et al. 2006 & Sweden \\
\hline K. alutacea (Fr.) Jülich \& Stalpers & KAS-GEL2284 & DQ340340 & unpublished & Germany \\
\hline
\end{tabular}




\begin{tabular}{|c|c|c|c|c|}
\hline K. barba-jovis (Bull.) P. Karst. & KHL 11730 (GB) & DQ873609 & Larsson et al. 2006 & Sweden \\
\hline K. cineracea (Bourdot \& Galzin) Jülich \& Stalpers & KAS-GEL4958 & DQ340336 & unpublished & La Réunion \\
\hline K. decorticans (Gresl. \& Rajchenb.) Hjortstam \& Ryvarden & SP415980 & KY081795 & Riebesehl \& Langer 2017 & Argentina \\
\hline K. efibulata (J. Erikss. \& Hjortstam) Jülich \& Stalpers & GB-0151167 & KY081796 & Riebesehl \& Langer 2017 & Sweden \\
\hline K. floccosa (Bourdot \& Galzin) Jülich \& Stalpers & UC2022902 & KP814441 & Rosenthal et al. 2017 & USA \\
\hline K. palmae Rick ex Hjortstam \& Ryvarden & FR7 & KP689185 & Wang et al. 2016 & China \\
\hline K. stereicola (Bres.) Nakasone & Blackwell 2141 & KY081797 & Riebesehl \& Langer 2017 & USA \\
\hline K. subalutacea (P. Karst.) Jülich \& Stalpers & KAS-GEL2196 & DQ340341 & unpublished & Norway \\
\hline $\begin{array}{l}\text { K. subefibulata (Jia J. Chen \& L.W. Zhou) Riebesehl \& E. } \\
\text { Langer }\end{array}$ & Dai 10803 & KT989971 & Chen et al. 2016 & China \\
\hline K. subglobosa (Sheng H. Wu) Hjortstam & Wu890805-2 & KY081798 & Riebesehl \& Langer 2017 & Taiwan \\
\hline $\begin{array}{l}\text { Lagarobasidium calongei M. Dueñas, Tellería, Melo, M.P. } \\
\text { Martín }\end{array}$ & MA-Fungi 73256 & NR119737 & Dueñas et al. 2009 & Azores Islands \\
\hline L. detriticum (Bourdot \& Galzin) Jülich & MA-Fungi 5758 & FM876211 & Dueñas et al. 2009 & Spain \\
\hline Lyomyces crustosus (Pers.) P. Karst. & YG-G39 & MF382993 & This study & Uzbekistan \\
\hline L. crustosus & UC2022841 & KP814310 & Rosenthal et al. 2017 & USA \\
\hline L. erastii (Saaren. \& Kotir.) Hjortstam \& Ryvarden & YG 022 & MF382992 & This study & Uzbekistan \\
\hline
\end{tabular}


L. erastii

L. griseliniae (G. Cunn.) Riebesehl \& E. Langer

L. juniperi (Bourdot \& Galzin) Riebesehl \& E. Langer

L. microfasciculatus (Yurchenko \& Sheng H. Wu)

Riebesehl \& E. Langer

L. sambuci (Pers.) P. Karst.

L. sambuci

L. sambuci

L. sambuci

L. sambuci

L. vietnamensis (Yurchenko \& Sheng H. Wu) Riebesehl \&

E. Langer

Palifer verecundus (G. Cunn.) Stalpers \& P.K. Buchanan

Phellinus gabonensis Decock \& Yombiyeni

Xylodon apacheriensis (Gilb. \& Canf.) Hjortstam \&

Ryvarden

X. asperus (Fr.) Hjortstam \& Ryvarden

$\begin{array}{llll}\text { MA-Fungi 34336 } & \text { JX857800 } & \text { unpublished } & \text { Spain } \\ \text { KHL 12971 (GB) } & \text { DQ873651 } & \text { Larsson et al. 2006 } & \text { Costa Rica } \\ \text { FR-0261086 } & \text { KY081799 } & \text { Riebesehl \& Langer 2017 } & \text { La Réunion } \\ \text { TNM F24757 } & \text { JN129976 } & \text { Yurchenko \& Wu 2014 } & \text { Taiwan } \\ \text { TAAM 104263 } & \text { MF382989 } & \text { This study } & \text { Uzbekistan } \\ \text { YG-G2 } & \text { MF382990 } & \text { This study } & \text { Uzbekistan } \\ \text { YG 036 } & \text { MF382991 } & \text { This study } & \text { Uzbekistan } \\ \text { KAS-GEL3400 } & \text { DQ340326 } & \text { unpublished } & \text { Taiwan } \\ \text { TFC Mic 15133 } & \text { JX857734 } & \text { unpublished } & \text { Spain } \\ \text { TNM F9073 } & \text { JX175044 } & \text { Yurchenko \& Wu 2014 } & \text { Vietnam } \\ \text { KHL 12261 (GB) } & \text { DQ873642 } & \text { Larsson et al. 2006 } & \text { USA } \\ \text { MUCL 52025 } & \text { HM635715 } & \text { Yombiyeni et al. 2011 } & \text { Gabon } \\ \text { Canfield 180 } & \text { KY081800 } & \text { Riebesehl \& Langer 2017 } & \text { USA } \\ \text { UC2023169 } & \text { KP814365 } & \text { Rosenthal et al. 2017 } & \text { USA }\end{array}$


X. astrocystidiatus (Yurchenko \& Sheng H. Wu) Riebesehl, Yurchenko \& E. Langer

X. borealis (Kotir. \& Saaren.) Hjortstam \& Ryvarden

X. dimiticus (Jia J. Chen \& L.W. Zhou) Riebesehl \& E.

Langer

China

X. flaviporus (Berk. \& M.A. Curtis ex Cooke) Riebesehl \&

\section{E. Langer}

\section{ICMP 13836}

Ryvarden 19767 ,

Wu 9209-27

Wu) Riebesehl, Yurchenko \& E. Langer

X. lenis Hjortstam \& Ryvarden

X. nespori (Bres.) Hjortstam \& Ryvarden

X. niemelaei (Sheng H. Wu) Hjortstam \& Ryvarden

X. nothofagi (G. Cunn.) Hjortstam \& Ryvarden

X. ovisporus (Corner) Riebesehl \& E. Langer

X. paradoxus (Schrad.) Chevall.

$\begin{array}{ll}\text { Wu890714-3 } & \text { KY081802 } \\ \text { KUC20130712-14 } & \text { KJ668518 } \\ \text { GC 1508-146 } & \text { KX857798 } \\ \text { PDD:91630 } & \text { GQ411524 } \\ \text { Wu0809-76 } & \text { KX857803 } \\ \text { FCUG 2425 } & \text { AF145571 }\end{array}$

JX175045

AF145585

KY081801

Riebesehl \& Langer 2017

Yurchenko \& Wu 2014

\section{Taiwan}

Riebesehl \& Langer 2017 Taiwan

Jang et al. 2016

Chen et al. 2017

Fukami et al. 2010

Chen et al. 2017

Paulus et al. 2000

\section{South Korea}

Taiwan

New Zealand

China

Russia 
X. pseudotropicus (C.L. Zhao, B.K. Cui \& Y.C. Dai)

Riebesehl, Yurchenko \& E. Langer

$$
\text { Dai } 10768
$$

KF917543

Otto Miettinen

X. quercinus (Pers.) Gray

X. raduloides (Pers.) Riebesehl \& E. Langer

X. ramicida Spirin \& Miettinen

X. rhizomorphus (C.L. Zhao, B.K. Cui \& Y.C. Dai)

Riebesehl, Yurchenko \& E. Langer

X. rimosissimus (Peck) Hjortstam \& Ryvarden

X. spathulatus (Schrad.) Kuntze

X. stratosus (Hjortstam \& Ryvarden) Hjortstam \&

Ryvarden

$\begin{array}{llll}\text { 15050,1 (H 6013352) } & \text { KT361632 } & \text { Ariyawansa et al. 2015 } & \text { Finland } \\ \text { ICMP 13833 } & \text { AF145580 } & \text { Paulus et al. 2000 } & \text { Australia } \\ \text { Viacheslav Spirin } & \text { KT361634 } & \text { Ariyawansa et al. 2015 } & \text { Russia } \\ \text { 7664 (H) } & & & \\ \text { Dai 12354 } & \text { KF917544 } & \text { Zhao et al. 2014 } & \text { China } \\ \text { Ryberg 021031 (GB) } & \text { DQ873627 } & \text { Larsson et al. 2006 } & \text { Sweden } \\ \text { KHL7085 (GB) } & \text { KY081804 } & \text { Riebesehl \& Langer 2017 } & \text { Sweden } \\ \text { LR9798 } & & & \\ & \text { KY081805 } & \text { Riebesehl \& Langer 2017 } & \text { Kenya }\end{array}$


Table 2. Summary of distribution and provisional ecological information on the Hyphodontia s.l. species in Central Asia [KZ, Kazakhstan; KG, Kyrgyzstan; TJ, Tajikistan; TM, Turkmenistan; UZ, Uzbekistan].

\begin{tabular}{|c|c|c|c|c|c|}
\hline Species & $\begin{array}{l}\text { Elevation } \\
\text { (m. a. s. l.) }\end{array}$ & Substrate/Host & Habitat and Ecology & Distribution & $\begin{array}{l}\text { Vegetation zone/ } \\
\text { Ecosystems }\end{array}$ \\
\hline $\begin{array}{l}\text { Hyphodontia } \\
\text { alutaria }\end{array}$ & $700-1800$ & $\begin{array}{l}\text { Juniperus } \\
\text { polycarpos var. } \\
\text { seravschanica, } \\
\text { Pterocarya } \\
\text { pterocarpa }\end{array}$ & $\begin{array}{l}\text { Coniferous and } \\
\text { deciduous forest in } \\
\text { foothills and Mountain } \\
\text { area. }\end{array}$ & TJ, UZ & $\begin{array}{l}\text { Boreal, mediterranean, temperate } \\
\text { oceanic, temperate continental, warm- } \\
\text { temperate desert, mixed-temperate }\end{array}$ \\
\hline H. arguta & $1700-2900$ & $\begin{array}{l}\text { Juniperus } \\
\text { communis var. } \\
\text { saxatilis, Picea } \\
\text { schrenkiana, } \\
\text { Sorbus } \\
\text { tianschanica, Abies } \\
\text { sibirica, Pinus } \\
\text { sylvestris, Malus } \\
\text { sieversii, Crataegus } \\
\text { songarica, } \\
\text { Phellinus pini }\end{array}$ & $\begin{array}{l}\text { Coniferous and } \\
\text { deciduous wood plants } \\
\text { in the xeric and moist } \\
\text { mountains forest }\end{array}$ & $\mathrm{KG}, \mathrm{KZ}, \mathrm{TJ}$ & $\begin{array}{l}\text { Boreal, mediterranean, temperate } \\
\text { oceanic, temperate continental, cold- } \\
\text { temperate, warm-temperate, tropical }\end{array}$ \\
\hline H. pallidula & 2100 & Picea sp. & $\begin{array}{l}\text { Coniferous forest in } \\
\text { moist mountain area }\end{array}$ & $\mathrm{KG}$ & Cold-temperate, boreal, tropical \\
\hline H. zhixiangii & $1700-2000$ & $\begin{array}{l}\text { Juniperus sp. and } \\
\text { Picea schrenkiana }\end{array}$ & $\begin{array}{l}\text { Coniferous forest in } \\
\text { Mountain area }\end{array}$ & $\mathrm{KZ}, \mathrm{UZ}$ & $\begin{array}{l}\text { Boreal, temperate continental, cold- } \\
\text { temperate, warm-temperate, tropical }\end{array}$ \\
\hline $\begin{array}{l}\text { Kneiffiella } \\
\text { alutacea }\end{array}$ & 2100 & Picea schrenkiana & $\begin{array}{l}\text { Coniferous forest in } \\
\text { Mountain area }\end{array}$ & $\mathrm{KZ}$ & $\begin{array}{l}\text { Boreal, boreo-nemoral, temperate } \\
\text { oceanic, temperate continental, } \\
\text { mediterranean, steppe -taiga, cold- } \\
\text { temperate }\end{array}$ \\
\hline K. floccosa & 2286 & Picea schrenkiana & $\begin{array}{l}\text { Coniferous forest in } \\
\text { Mountain moist area }\end{array}$ & $\mathrm{KZ}$ & $\begin{array}{l}\text { Boreal, temperate continental, } \\
\text { temperate oceanic }\end{array}$ \\
\hline $\begin{array}{l}\text { Lyomyces } \\
\text { crustosus }\end{array}$ & $1250-2100$ & $\begin{array}{l}\text { Crataegus azarolus } \\
\text { var. pontica, } \\
\text { Fraxinus } \\
\text { pennsylvanica, } \\
\text { Unknown } \\
\text { deciduous wood }\end{array}$ & $\begin{array}{l}\text { Deserts shrublands and } \\
\text { xeric mountain forest }\end{array}$ & $\begin{array}{l}\mathrm{KG}, \mathrm{TM} \\
\mathrm{UZ}\end{array}$ & $\begin{array}{l}\text { Boreal,temperate continental, } \\
\text { temperate oceanic, mediterranean, } \\
\text { warm-temperate desert, mixed- } \\
\text { temperate }\end{array}$ \\
\hline L. erastii & 1800 & $\begin{array}{l}\text { Unknown } \\
\text { deciduous wood }\end{array}$ & $\begin{array}{l}\text { Deciduous forest in } \\
\text { mountain area }\end{array}$ & $\mathrm{UZ}$ & $\begin{array}{l}\text { Boreal,warm-temperate desert and } \\
\text { semi desert, mediterranean }\end{array}$ \\
\hline L. pruni & $750-2413$ & Fraxinus sp. & $\begin{array}{l}\text { Deciduous xerophytic } \\
\text { light forests in } \\
\text { steppe/arid to mountain } \\
\text { zone }\end{array}$ & $\mathrm{KZ}$ & $\begin{array}{l}\text { Temperate continental, temperate } \\
\text { oceanic, boreal, tropical, } \\
\text { mediterranean, warm temperate desert }\end{array}$ \\
\hline L. sambuci & $1000-2500$ & $\begin{array}{l}\text { Unknown died } \\
\text { wood, tree branch, } \\
\text { Juniperus } \\
\text { pseudosabina, } \\
\text { Populus pruinosa, } \\
\text { Philadelphus sp., } \\
\text { Acer turcomanicum }\end{array}$ & $\begin{array}{l}\text { Xerophytic deciduous } \\
\text { forest-steppe and moist } \\
\text { coniferous forests in } \\
\text { mountain area. }\end{array}$ & TJ, TM, UZ & $\begin{array}{l}\text { Warm temperate desert, temperate } \\
\text { oceanic, boreal, tropical }\end{array}$ \\
\hline $\begin{array}{l}\text { Xylodon } \\
\text { asperus }\end{array}$ & $1700-2300$ & $\begin{array}{l}\text { Populus talassica, } \\
\text { P. tremula }\end{array}$ & $\begin{array}{l}\text { Deciduous forest wood } \\
\text { in mountain area. }\end{array}$ & $\mathrm{KZ}$ & $\begin{array}{l}\text { temperate continental, subtropical, } \\
\text { boreal, forest steppe }\end{array}$ \\
\hline
\end{tabular}

